biomass under optimal growing conditions in Costa Rica. Agrofor. Syst., 2010, 78, 269-286.

33. Bakker, M. R., Augusto, L. and Achat, D. L., Fine root distribution of trees and understory in mature stands of maritime pine (Pinus pinaster) on dry and humid sites. Plant Soil, 2006, 286, 37-51.

34. Pei, Y., Lei, P., Xiang, W., Ouyang, S. D. and Xu, Y., Effect of stand age on fine root biomass, production and morphology in Chinese fir plantations in subtropical China. Sustainability, 2018, 10(7), 2280

35. Vitousek, P. M. and Sanford Jr, R. L., Nutrient cycling in moist tropical forest. Annu. Rev. Ecol. Syst., 1986, 17, 137-167.

36. Taugourdeau, S. et al., Leaf area index as an indicator of ecosystem services and management practices: an application for coffee agroforestry. Agric. Ecosyst. Environ., 2014, 192, 19-37.

37. Khiewtam, R. S. and Ramakrishnan, P. S., Litter and fine roo dynamics of a relic sacred grove forest at Cherrapunji. For. Ecol. Manage., 1993, 60, 327-344.

38. Upadhaya, K., Pandey, H. N., Law, P. S. and Tripathi, R. S., Dynamics of fine and coarse roots and nitrogen mineralization in a humid subtropical forest ecosystem of north east India. Biol. Fertil. Soils, 2005, 41, 144-152.

39. King, J. S., Albaugh, T. J., Allen, H. L., Buford, M., Strain, B. R. and Dougherty, P., Below-ground carbon input to soil is controlled by nutrient availability and fine root dynamics in loblolly pine. New Phytol., 2002, 154, 389-398.

40. Silver, W. L. et al., Fine root dynamics and trace gas fluxes in two lowland tropical forest soils. Global Change Biol., 2005, 11, 290360 .

41. Gill, R. A. and Jackson, R. B., Global patterns of root turnover for terrestrial ecosystems. New Phytol., 2000, 147, 13-31.

42. Newaj, R., Chavan, S. B., Alam, B. and Dhyani, S. K., Biomass and carbon storage in trees grown under different agroforestry systems in semi arid region of Central India. Indian For., 2016, 142(7), 642-648.

ACKNOWLEDGEMENTS. We thank the Indian Council of Agricultural Research (ICAR), New Delhi and ICAR-Central Agroforestry Research Institute, Jhansi for providing funds. We also thank our colleagues for cooperation and help during the course of this study.

Received 15 April 2020; accepted 23 September 2020

\section{Why primary processing of herbal raw drugs is important}

\author{
Vinod K. Bisht ${ }^{1, *}$ and Ramesh C. Uniyal ${ }^{2}$ \\ ${ }^{1}$ Zandu Foundation for Health Care, Ambach, Pardi 396 145, India \\ ${ }^{2}$ Bioresources Development, Emami Ltd, 687, Anandapur, \\ EM Bypass, Kolkata 700 107, India
}

The present study was carried out to analyse foreign matter (FM) in herbal raw drugs (HRDs), as it deteriorates the quality and therapeutic efficacy of the endproduct. A total of 35 HRDs representing 11 different parts were analysed. For each drug, 3-8 samples with each sample having 5-500 $\mathrm{kg}$ of drugs were collected. The FM was found to vary from $2.59 \%$ to $47.48 \%$, and none of the drugs complied with the parameters of Ayurvedic Pharmacopoeia of India (API). Nearly $\mathbf{4 8 . 5 7 \%}$ of the drugs in the Indian market are traded with more than $10 \%$ of $F M$ in them. The FM in most of the drugs is contributed by components other than official drugs of the same species. The quality of raw drugs can be enhanced by making them free of FM or reducing it to the permissible limits of $A P I$, with the execution of good agriculture and collection practices and good field collection practices. Proper supply chain management of quality raw drugs may be assured by developing infrastructure like establishment of new and strengthening of existing mandis (herbal collection and retail/wholesale outlets) having post-harvest processing facilities. Measures like, linkages between farmers and buyers, and buy-back interventions through on-line virtual platforms such as e-charak and e-NAM must also be taken into consideration. In conclusion, a comprehensive nationallevel policy/strategy is needed to address various issues pertaining to the quality and marketing of HRDs.

Keywords: Foreign matter, herbal raw drugs, market linkages, medicinal plants, post-harvest management.

IN India, 1622 herbal raw drugs (HRDs) belonging to 1178 medicinal plants are in commercial trade ${ }^{1}$. The official accepted HRDs comprise of root, rhizome, bark, stem, leaf, flower, fruit, fruit rind, seed, heartwood, aerial part, whole plant, gum, resin, etc. The total estimated consumption of HRDs is 512,000 MT, with corresponding trade value of ₹7000 crore for 2014-15 (ref. 1). Out of 1178 species, 242 are traded in quantities exceeding $100 \mathrm{MT}$ per year. HRDs belonging to 198 species account for about $95 \%$ of the total such drugs consumed by India's herbal industry ${ }^{1}$. In the last two decades, the Indian herbal sector has witnessed an annual growth of $>10 \%$ and is emerging as a major economic activity ${ }^{2}$.

With growing recognition for these resources, the herbal industries require large quantities of HRDs. This

*For correspondence. (e-mail: vksbisht@gmail.com) 
demand is met through vendors situated throughout in the country, who source them either from cultivation, wild or imports. Nearly $85 \%$ of HRDs and $70 \%$ of the annual quantities consumed are sourced from the wild ${ }^{1}$. The quality of HRDs plays a vital role in the end-product quality. However, the HRDs traded in India have high foreign matter (FM) in them. FM is a part of HRDs other than official drugs of the same or other species, any organism, part or product of an organism, animal dung, or mineral admixtures such as soil, stones, sand, etc. ${ }^{3}$. High FM along with adulteration results in substandard HRDs, which affects the chemical composition of the active ingredients and deteriorates the quality and therapeutic efficacy of the end-product ${ }^{2}$. In the present study, we examine the extent of FM in most of the common and widely used HRDs in herbal industries.

HRDs belonging to 35 species were collected from traders situated in different states of India such as Uttarakhand, Delhi, Punjab, Madhya Pradesh, Chhattisgarh, West Bengal, Maharashtra and Telangana. These are among the most common and widely used species in herbal industries and are available at the time of sample collection. The HRDs included in the study were aerial part (two species), flower (one species), fruit (one species), fruit rind (three species), heartwood (one species), leaf (three species), rhizome (one species), root (ten species), seed (five species), stem (two species) and whole plant (six species) (Table 1). We mostly included species through which maximum number of accepted HRDs are being traded. For each drug, minimum of three and maximum of eight samples were collected having minimum $5 \mathrm{~kg}$ and maximum $500 \mathrm{~kg}$ of HRDs. The cumulative quantity of HRDs collected for the present study varied from a minimum of $25 \mathrm{~kg}$ (flower; Nelumbo nucifera) to a maximum of $3570 \mathrm{~kg}$ (fruit; Vitis vinifera) (Table 1). The FM was calculated as per description given in Ayurvedic Pharmacopoeia of India $(A P I)^{3}$.

The FM were found to vary from $2.59 \%$ to $47.48 \%$ in different HRDs. Among 35 HRDs studied, 51.43\% (18 HRDs) were found to be traded with less than $10 \% \mathrm{FM}$, $27 \%$ ( 8 HRDs) were traded with $11-20 \%$ FM and $26 \%$ (9 HRDs) were traded with more than $20 \%$ FM. Thus, nearly $48.57 \%$ (17 HRDs) traded in the Indian market have more than $10 \%$ of the FM in them. Maximum FM of $47.48 \%$ was observed in leaf (Justicia adhatoda) followed by whole plant $(39.64 \%, 39.32 \%$ and $31.85 \%$ respectively, in Eclipta prostrata, Vetiveria zizanioides and Fumaria parviflora). It was observed that, none of the HRDs had permissible limits of FM according to API. However, Inula racemosa root and Trachyspermum ammi seed were the only HRDs where the FM was found comparable with the permissible limits of API (Table 1). It was observed that the other parts of the same species also contribute to the FM. For example, the petiole in flowers (N. nucifera), stem and leaf parts in fruits ( $V$. vinifera), seed/stone in fruit rind (Phyllanthus emblica, Terminalia chebula, Terminalia bellirica), stem part or collar part in roots (Clerodendrum phlomidis, Ricinus communis, Oroxylum indicum, Piper longum, Plumbago zeylanica, Inula racemosa), aerial part in roots (Piper longum) (Table 1). However, in HRDs where the whole plant is traded such as E. prostrata, $V$. zizanioides, $F$. parviflora, Boerhaavia diffusa and Bacopa monnieri, the soil intact with roots contributes to a major part of FM. It was also noted that there was remarkable variation in FM of different samples of HRDs. This may be attributed to the fact that most of the material was collected from different sources. However, Srirama et al. ${ }^{5}$ reported that adulteration or high FM in HRDs could be intentional, or due to lack of knowledge of good collection practices at the primary level. The dead, decomposed, rusted or infected parts of genuine HRDs also contribute to some extent to FM. In Tinospora cordifolia (stem), the rotted, infected and decomposed stems contribute to the total FM, thus indicating the importance of proper post-harvest management.

Several studies have reported adulteration in HRDs. Srirama et $a l .^{4}$ found that Phyllanthus amarus was often mixed with six other species of Phyllanthus. Seethapathy et $a .^{5}$ reported 50\% admixture in Senna auriculata, 37\% in Senna tora and 8\% in Senna alexandrina. In Sida species, over $80 \%$ adulteration was reported ${ }^{6}$. However, the $A P I$ has classified the limits of FM for each HRD, but intentional adulteration, improper handling after harvesting and lack of regulatory tools in commercial tests for HRD authentication often result in higher percentage of FM in HRDs $^{1,5}$. It is estimated that nearly $3 \%$ of the HRDs were wasted only due to improper handling ${ }^{1}$, while the total loss due to poor infrastructure for storage, processing and marketing was reported to vary between $10 \%$ and $40 \%$ (ref. 2). Poor quality of HRD with such adulteration could have detrimental health implications ${ }^{2,6}$. For example, an admixture of walnut in Echinaceae, can lead to severe nut allergies in consumers ${ }^{7}$. Likewise, the roots of a toxic herb Aristolochia fangchi when mixed with roots of Stephania tetrandra, lead to kidney failure ${ }^{8}$. Thus, before use, the industries required huge labour input to sort out these HRDs according to the API limits of FM which may hamper the production plan and also increase production cost.

The Government of India has notified 'good manufacturing practices (GMP)' under Schedule ' $T$ ' of the Drugs and Cosmetics Act, 1940 to ensure and enhance the quality of herbal medicines. Thus, quality of HRDs is important as it plays a key role in achieving safe and effective therapeutic potency. The quality of HRDs can be enhanced by making them free of FM or reducing it to the permitted limits of API using good agriculture and collection practices $^{9}$, and good field collection practices ${ }^{10}$. Application of these practices along with facilitating market linkages will subsequently support the growers in fetching better economic returns as in case of Cinnamomum tamala 
RESEARCH COMMUNICATIONS

Table 1. Herbal raw drugs (HRDs) with foreign matter (FM) and limit of FM according to Ayurvedic Pharmacopoeia of India (API)

\begin{tabular}{|c|c|c|c|c|c|c|}
\hline \multirow[b]{2}{*}{ Part used } & \multirow[b]{2}{*}{ Species (trade name) } & \multirow{2}{*}{$\begin{array}{l}\text { Quantity of HRD } \\
\text { analysed }(\mathrm{kg})\end{array}$} & \multirow{2}{*}{$\begin{array}{l}\text { Number of } \\
\text { samples }\end{array}$} & \multicolumn{2}{|c|}{ FM } & \multirow{2}{*}{$\begin{array}{l}A P I \text { limit }(\%) \text { of } \\
\text { foreign matter* }\end{array}$} \\
\hline & & & & $\% \pm \mathrm{SD}^{\#}$ & Material & \\
\hline \multirow[t]{2}{*}{ Aerial part } & Datura metel L. (Dhatura) & 150 & 3 & $15.62 \pm 11.33$ & Fruit part & 2 \\
\hline & $\begin{array}{l}\text { Desmodium gangeticum (L.) DC. } \\
\quad \text { (Salparni) }\end{array}$ & 155 & 3 & $18.14 \pm 8.66$ & Soil, stone & 2 \\
\hline Flower & $\begin{array}{l}\text { Nelumbo nucifera Gaertn. } \\
\quad \text { (Kamalphool) }\end{array}$ & 25 & 3 & $4.00 \pm 1.66$ & Petiole & 2 \\
\hline Fruit & Vitis vinifera L. (Draksha) & 3570 & 8 & $6.84 \pm 7.12$ & Leaves, stem & 2 \\
\hline \multirow[t]{3}{*}{ Fruit rind } & Phyllanthus emblica L. (Amla) & 838 & 4 & $20.26 \pm 6.40$ & Seed & 3 \\
\hline & $\begin{array}{l}\text { Terminalia bellirica (Gaertn.) Roxb. } \\
\text { (Baheda) }\end{array}$ & 1467 & 7 & $28.53 \pm 6.14$ & Seed & 2 \\
\hline & Terminalia chebula Retz. (Haritaki) & 1081 & 5 & $11.93 \pm 6.40$ & Seed & 1 \\
\hline Heart wood & $\begin{array}{l}\text { Prunus cerasoides Buch.-Ham. ex. } \\
\text { D. Don (Padamkastha) }\end{array}$ & 100 & 3 & $21.50 \pm 10.33$ & $\begin{array}{l}\text { Stem, stem } \\
\text { bark }\end{array}$ & 1 \\
\hline \multirow[t]{3}{*}{ Leaf } & Justicia adhatoda L. (Ardushi) & 373 & 5 & $47.48 \pm 6.40$ & Stem & 2 \\
\hline & Ocimum tenuiflorum L. (Tulsi) & 182 & 4 & $19.05 \pm 3.75$ & Stem & 2 \\
\hline & $\begin{array}{l}\text { Pluchea lanceolata (DC.) C.B. } \\
\text { Clarke (Rasna) }\end{array}$ & 2519 & 8 & $30.11 \pm 3.12$ & Stem & 2 \\
\hline Rhizome & $\begin{array}{l}\text { Hedychium spicatum } \mathrm{Sm} \text {. (Kapur } \\
\text { Kachri) }\end{array}$ & 150 & 4 & $8.31 \pm 4.60$ & Stem & 1 \\
\hline \multirow[t]{9}{*}{ Root } & $\begin{array}{l}\text { Clerodendrum phlomidis L. f. } \\
\text { (Agnimantha) }\end{array}$ & 1150 & 6 & $24.26 \pm 6.17$ & Stem & 2 \\
\hline & Cyperus rotundus L. (Nagarmotha) & 150 & 4 & $8.00 \pm 3.75$ & Soil & 2 \\
\hline & $\begin{array}{l}\text { Inula racemosa Hook .f. } \\
\quad \text { (Puskarmool) }\end{array}$ & 2318 & 4 & $2.59 \pm 5.80$ & Stem & 2 \\
\hline & $\begin{array}{l}\text { Operculina turpethum (L.) } \\
\text { Silva Manso (Nasotar) }\end{array}$ & 536 & 4 & $6.90 \pm 3.50$ & Stem & Nil \\
\hline & $\begin{array}{l}\text { Oroxylum indicum (L.) Kurz } \\
\quad \text { (Syonaka) }\end{array}$ & 150 & 3 & $9.19 \pm 6.33$ & Stem & 1 \\
\hline & Piper retrofractum Vahl. (Chavya) & 358 & 4 & $14.93 \pm 4.50$ & Leaf, root & 2 \\
\hline & Plumbago zeylanica L. (Chitrak) & 50 & 3 & $6.01 \pm 8.33$ & Soil & 3 \\
\hline & Ricinus communis L. (Erand) & 248 & 4 & $15.94 \pm 7.25$ & Soil, stem & 2 \\
\hline & $\begin{array}{l}\text { Tylophora asthmatica (L.f.) } \\
\text { Wight \& Arn. (Antamool) }\end{array}$ & 491 & 5 & $8.63 \pm 4.60$ & Stem & NA \\
\hline \multirow[t]{5}{*}{ Seed } & Cassia tora L. (Prapunnada) & 46 & 3 & $7.82 \pm 5.66$ & $\begin{array}{l}\text { Stone, fruit } \\
\text { part }\end{array}$ & 2 \\
\hline & $\begin{array}{l}\text { Holarrhena antidysenterica (Roth.) } \\
\text { Wall. ex. A. DC. (Indrajau) }\end{array}$ & 150 & 3 & $16.86 \pm 5.33$ & Stone & 2 \\
\hline & Psoralea corylifolia L. (Bakuchi) & 55 & 3 & $8.09 \pm 4.33$ & $\begin{array}{l}\text { Stone, fruit } \\
\text { part }\end{array}$ & 2 \\
\hline & Sida cordifolia L. (Bala) & 426 & 3 & $7.56 \pm 5.33$ & $\begin{array}{l}\text { Stone, fruit } \\
\text { part }\end{array}$ & NA \\
\hline & $\begin{array}{l}\text { Trachyspermum ammi (L.) Sprague } \\
\quad \text { (Yavani) }\end{array}$ & 38 & 3 & $6.00 \pm 8.33$ & Fruit part & 5 \\
\hline \multirow[t]{2}{*}{ Stem } & $\begin{array}{l}\text { Baliospermum montanum (Willd.) } \\
\text { Mull. Arg. (Dantimul) }\end{array}$ & 104 & 3 & $6.40 \pm 4.66$ & Collar part & 2 \\
\hline & $\begin{array}{l}\text { Tinospora cordifolia (Willd.) } \\
\text { Miers (Guduchi) }\end{array}$ & 100 & 3 & $13.37 \pm 7.66$ & $\begin{array}{l}\text { Decomposed } \\
\text { stem }\end{array}$ & 2 \\
\hline \multirow[t]{6}{*}{ Whole plant } & $\begin{array}{l}\text { Bacopa monnieri (L.) Wettst. } \\
\quad \text { (Brahmi) }\end{array}$ & 150 & 3 & $4.26 \pm 7.66$ & Soil & 2 \\
\hline & Boerhaavia diffusa L. (Punarnava) & 50 & 3 & $5.72 \pm 8.33$ & Soil & 2 \\
\hline & Eclipta prostrata (L.) L. (Bhringraj) & 251 & 5 & $39.64 \pm 7.20$ & Soil & 2 \\
\hline & Fumaria parviflora Lam. (Parpata) & 105 & 4 & $31.85 \pm 4.25$ & Soil & 2 \\
\hline & Solanum indicum L. (Brahati) & 60 & 3 & $13.04 \pm 5.66$ & Soil & 2 \\
\hline & $\begin{array}{l}\text { Vetiveria zizanioides (L.) Nash } \\
\text { (Ushira) }\end{array}$ & 89 & 3 & $39.32 \pm 5.33$ & Soil & 2 \\
\hline
\end{tabular}

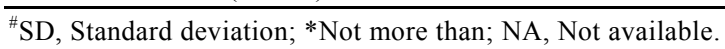


from Uttarakhand ${ }^{11}$, and help industries to reduce labour cost required for the cleaning of HRDs. Proper supply chain management is also crucial for sustenance of the sector and may be strengthened by establishing Farmer Producer Organizations/Farmer Producer Companies and developing marketing infrastructure. Primary processing and value addition along with strengthening of marketing network should be considered for regular supply of quality HRDs to industries ${ }^{2}$. This can be achieved by establishing new and strengthening existing herbal collection and retail/wholesale outlets (mandis) with post-harvest processing and testing facilities. Linkages between farmers and buyers, and buy-back interventions through on-line virtual platforms such as e-charak and e-NAM are other measures that can be taken into consideration. In conclusion, a comprehensive national-level policy/ strategy is needed to address various issues pertaining to the cultivation, collection, processing, harvesting, quality and marketing of HRDs.

1. Goraya, G. S. and Ved, D. K., Medicinal Plants in India: An Assessment of their Demand and Supply, Government of India (GoI), Dehradun, 2017, pp. 1-430.

2. Bisht, V. K. et al., Post-harvest techniques for medicinal and aromatic plants. In Ethnobotany and Medicinal Plants (eds Bharti, P. K. and Chauhan, A.), Ancient Publishing House, Delhi, 2013, pp. $28-45$.

3. Ayurvedic Pharmacopoeia of India, Department of AYUSH, Ministry of Health and Family Welfare (MoHFW), GoI, 2008, vols I-IX.

4. Srirama, R. et al., Assessing species admixtures in raw drugs trade of Phyllanthus, a hepatoproctective plant using molecular tools. J. Ethnopharmacol., 2010, 130, 208-215.

5. Seethapathy, G. S. et al., Assessing product adulteration in natural health products for laxative yielding plants, Cassia, Senna and Chamaecrista, in southern India using DNA barcoding. Int. J. Legal Med., 2015, 129(4), 693-700.

6. Santosh, K. J. U. et al., DNA barcoding to assess species adulteration in raw drug trade of 'Bala' (genus: Sida L.). Biochem. Syst. Ecol., 2015, 61, 501-509.

7. Wallace, L. J. et al., DNA barcodes for everyday life: routine authentication of natural health products. Food Res. Int., 2012, 49, 446-452.

8. Gilbert, N., Herbal medicine rule book: can Western guidelines govern eastern herbal traditions? Nature, 2011, 480, S98-S99.

9. WHO, Guidelines on Good Agricultural and Collection Practices for Medicinal Plants, World Health Organization, Geneva, 2003.

10. NMPB, Guidelines on Good Field Collection Practices for Indian Medicinal Plants, National Medicinal Plants Board, MoHFW, GoI, 2009.

11. Kuniyal, C. P. and Bisht, V. K., Impact of facilitation on marketing of tejpat (Cinnamomum tamala) from non-forest areas in Uttarakhand, Western Himalaya. Natl. Acad. Sci. Lett., 2015, 38(1), 91-92.

Received 10 July 2020; revised accepted 19 September 2020

doi: $10.18520 / \mathrm{cs} / \mathrm{v} 119 / \mathrm{i} 10 / 1699-1702$

\section{Examining the trapping efficiency of different coloured light emitting diodes in combination with the host plant for monitoring and managing banana weevils}

\author{
Mani Kannan, Balakrishnan Padmanaban*, \\ Kammatterikunnu Ashif, Narayanan Baskar and \\ Subbaraya Uma
}

ICAR-National Research Centre for Banana, Thayanur, Thogamalai Road, Tiruchirappalli 620 102, India

\begin{abstract}
Light emitting diode (LED)-based insect monitoring approach is drawing the attention of researchers. In the present study, we evaluated the insect pest response to four different coloured LEDs (blue, green, red and warm white or yellow) in the laboratory (darkroom) and in field conditions. The field studies indicated that Odoiporus longicollis is attracted to blue LED with a longitudinal split banana stem trap (LSBST), with an average of $7 \pm 1$ weevils per trap, compared to other LEDs and LSBST. However, the corm weevil was not attracted to the traps significantly. To confirm the weevil response to LED trap, an experiment was performed in the laboratory. Interestingly, the laboratory experiment indicated a higher attraction of $O$. longicollis towards blue LED + LSBST with $63 \pm 5.77 \%$ in male and $53.33 \pm 5.77 \%$ in female, and of Cosmopolites sordidus with $43.33 \pm 5.77 \%$ in both male and female when compared with other traps. The overall results suggest that blue LED can be used as a light trap for monitoring as well as the mass trapping of banana weevils in the garden.
\end{abstract}

Keywords: Banana weevils, integrated pest management, light-emitting diode, trapping efficiency.

BANANA is one of the most important and preferred dietary fruit crops, but its production remains insufficient for the rapidly growing population ${ }^{1}$. Banana weevils (Cosmopolites sordidus and Odoiporous longicollis) affect the growth and yield of banana cultivars like Nendran, Poovan $(\mathrm{AAB})$, Karpuravalli and Monthan $(\mathrm{ABB})^{2-4}$. C. sordidus and $O$. longicollis adults lay their eggs on the outer leaf sheath and corm respectively, and live inside the freshly cut pseudostem or dead plants. The larvae of $O$. longicollis feed on the pseudostem by making a tunnel which leads to stem break and the plant is damaged. $C$. sordidus weevils feed on corm and prevent sucker or mate formation, which results in the plant producing small or immature bunches. These weevils cause production loss ranging from $10 \%$ to $90 \%$ (refs $2-4$ ). Since adult weevils and grubs live within the pseudostem, it is

\footnotetext{
*For correspondence. (e-mail: bpadmanabannrcb@gmail.com)
} 